\title{
Pollen Viability of Date Palm from Different Sources in Relation to its Chemical Composition
}

\author{
M. Abdel-Sattar ${ }^{1}$ and Y.I. Mohamed ${ }^{2}$ \\ ${ }^{1}$ Pomology Department, Faculty of Agriculture (El-Shatby), Alexandria Univ., Egypt. \\ ${ }^{2}$ Faculty of Desert and Environmental Agriculture Fuka, Matrouh, Alexandria, Egypt. \\ Corresponding Author: M. abdel-sattar Fax: +2035922780, \\ Email: mahmoud.hassan@alexu.edu.eg
}

\begin{abstract}
This study was undertaken to determine pollen viability for nine pollen grain sources of date palm from three sites in Arab Republic of Egypt using staining and germination methods, in addition, to recording the differences in the chemical composition i.e., total carbohydrates, protein and amino acids, as well as, the relationship between them. This experiment was carried out to select the amino acids that can be used in the future to improve pollen viability and to increase productivity of date palm using suitable male palms by modern methods. Therefore, three selected males from three sites in three governorates i.e., El-Behira, El-Fayoum and Sohag were chosen for this study. Results showed that pollen grains brought from Rasheed, El Behera governorate (M1) produced the highest staining and germination percentages (91 and $84 \%$, respectively), as well as the highest protein content of $31.21 \%$. Similarly M1 had the highest lysine and serine content (6.41 and 4.80, respectively), as compared to the other pollen sources. There was a highly positive correlation between both stained and germinated pollens with the arginine content $(r=0.693$ and 0.700$)$ respectively. The principal component analysis was performed to clarify the relationship between the evaluated variables i.e. chemical composition revealed that the first four components (PCA1, PCA2, PCA3 and PCA4) accounted for more than 83\% of the total variations for the variables. The biplot showed that there was a high correlation between the stained, germinated pollen grains and the content of lysine and arginine.
\end{abstract}

Date palm, Phoenix dactylifera, Stained, Germination, Pollens, Chemical Composition.

\section{INTRODUCTION}

Date palm (Phoenix dactylifera L.) is dioecious and is naturally cross pollinated. Under commercial cultivation, female palms are artificially pollinated using compatible pollen source. However, artificial hand pollination represents a great task for the date growers, and such a practice should be done using the most viable pollens in order to get the highest fruit set and yield (El-Hammady et al., 1977; Khalifa et al., 1980; El-Makhtoun, 1981; Hamdy, 1982 and Rabie, 2007). They reported that pollen sources vary in their influence on the physical and chemical characteristics of fruit. These variations are accounted for genetic or environmental factors or for the interaction between both. In the meantime, date growers use any pollen source that is readily available without paying any attention to the choice of proper type. However, to get best set and yield they should select the appropriate male type as a source of pollen.

Many studies have addressed the use of different pollen grain sources on yield and fruit characteristics of date palms (Iqbal et al., 2008 Mustafa et al., 2014, Merwad et al., 2015 and Nesiem et al., 2016). The different sources usually have different pollen viability (Bacha et al., 2000). The term viability refers to the capacity of the pollen to germinate and grow normally, high viable pollen will improve the fruit set and ultimately will produce higher yield. In vitro germination is a valuable technique to determine the viability of the pollen grains and to identify the best pollinators for the pollination process (Ibrahim et al., 2014). Pollen viability is determined in different fruit species using the two methods of germination and Acetocarmine staining (Bacha et al., 2000).

At present, very little is known about the impact of pollen source and its chemical composition on its viability. Thus, the present study aims to declare the relationship between the viability of pollen grains from different sources and their chemical composition to select the suitable source of pollen for increasing the production of palm trees as well as accumulation of information about the reasons to modify this character (pollen viability).

\section{MATERIALS AND METHODS}

This investigation was carried out during the 2014 using nine date palm males grown in different Egyptian governorates (Table, 1). Four mature spathes were randomly collected from each male tree. The strands were dried out at room temperature for seven days. The pollen grains were separated from the strands using a sieve, and then pollen grains were transferred to stopper bottles and stored in a dry place at room temperature.

\section{Viability determination}

Two general methods assaying pollen viability were used: 


\section{1- Staining test}

The dehiscent pollens were lightly tapped on a drop of $1 \%$ acetocamine stain on a slide. Six slides were made for each pollen source, for each slide ten microscopic fields were randomly chosen and pollen grains were counted and graded as viable and aborted in two classes. The pollen grains which darkly stained and round pollen grains were considered viable, while those lightly stained or shrunk were considered aborted. This technique was previously described by Ibrahim (1989) and ElMakhtoun and Abd El-Kader (1990).

\section{2- Germination test}

A mixture of pollen grains from each pollen source was collected in clean Petri dishes to minimize variations that might exist between pollen grains of the same spathe of a given source. The basic medium in Petri dishes was prepared by adding $2 \mathrm{~g}$ sucrose, $1 \mathrm{~g}$ agar and $15 \mathrm{ppm}$ boric acid per $100 \mathrm{ml}$ water, and then was boiled. Ten milliliters of the mixture was poured into every sterile Petri dish. Five dishes from each pollen source were used as replications. Pollens were carefully sown on the medium of each dish, and then all dishes were incubated at $25^{\circ} \mathrm{C}$ for $10 \mathrm{hrs}$. Randomly count of 100 pollen grains was made in each replication under $600 \times$ magnifications. This technique has been previously reported by Hamdy (1982).

\section{Chemical composition}

Total carbohydrates and sugars were determined according to Malik and Singh (1980), while crude protein was determined by multiplying nitrogen determined by the micro Kjeldahl method (A.O.A.C, 1995 ) by 6.25 . The results were expressed as $g / 100$ $\mathrm{g}$ or percent on dry weight basis. In addition, amino acids content in protein hydrolyzate was detected using Amino Acid Analyzer according to Moore et al., (1958). The concentration of amino acids were calculated as grams per 100 grams of protein on dry weight basis. Backman Amino Acid Analyzer Model 119CL (according to the methods of Block et al., 1958) was used for amino acid determination in pollen grains materials.

\section{Statistical analysis}

The data obtained throughout this study were separated and compared using least significant difference (L.S.D.) at 0.05 level of probability according to Snedecor and Cochran (1980). The statistical analysis was performed using SAS (Statistical Analysis System) version 9.13, (2008). In addition correlation analysis among the pollen viability and their chemical composition was performed to determine the best indicator for the pollen viability. Principal component analysis (PCA) was performed based on the observations. Both correlation and PCA were performed using Microsoft R Excel 2013/XLSTATc-Pro by Fahmy, 2015 (Version, 2015.6.01.23953, Addinsoft, Inc., Brooklyn, NY, USA).
Table 1: Pollen grain sources

\begin{tabular}{cl}
\hline No. Male & \multicolumn{1}{c}{ Source } \\
\hline M1 & Rasheed, EL-Behira governorate \\
M2 & Edko, EL-Behira governorate \\
M3 & Hosh-Isa, EL-Behira governorate \\
M4 & Sinnuris, El-Fayoum governorate \\
M5 & Tamiyyah, El-Fayoum governorate \\
M6 & Ibshaway, El-Fayoum governorate \\
M7 & El-Maragha, Sohage governorate \\
M8 & Tema, Sohage governorate, \\
M9 & Tahta, Sohage governorate \\
\hline
\end{tabular}

\section{RESULTS AND DISCUSSION Viability determination}

The date presented in Table (2) cleared that, the male source number M1 had the highest staining percentage value of $91 \%$ as compared to all other pollen sources having no significant difference with M2, M4, M6 and M8. On the other hand, male M7 recorded the lowest significant staining percentage as compared to the other pollen sources except with M3 and M9. In the meantime, M2, M4 and M6 did not significantly differ among each other and had higher staining percentage than M7 and M9. Additionally, almost similar trend was followed by conducting the germination test for all the male sources. M1 had significantly the highest germination percentage value i.e. $84 \%$ as compared to all other pollen source, while M7 had the lowest values of germination percentage. These results are inagreement with previous findings of other investigators who studied some physical characteristics of the inflorescence of different date palm males (Bacha et. al., 1988; Rabie, 2007 and Nesiem et al., 2016). They all indicated that the different pollen grains of different sources showed a wide variation in both staining and germination percentages.

\section{Chemical composition}

Data in Table (2) show that M5 had significantly the highest total sugars percentage $(8.61 \%)$ as compared to all other sources, while both M7 and M9 had the lowest sugar content. In addition, M8 recorded the highest significant total carbohydrates of $18.75 \%$ as compared to the other pollen sources. However, M3 had the lowest total carbohydrates percentage. Furthermore, M1 recorded the highest protein percentage of $31.21 \%$ in comparison to all other sources, whereas, M9 had significantly lower protein percentage than all other sources.

The genotypic differences and the environmental factors highly influenced the chemical composition of the pollen grains during maturation and after dehiscence (Stanley, 1971). 
Table 2: The percentage of viability and total sugars, total carbohydrate and protein content of different date palm pollen sources

\begin{tabular}{lccccc}
\hline No. Male & \multicolumn{2}{c}{ Pollen viability } & \multicolumn{3}{c}{ Chemical composition } \\
\cline { 2 - 6 } & Germination & Staining & Total sugars & Total carbohydrates & Protein \\
\hline M1 & 91.00 & 84.00 & 6.52 & 14.31 & 31.21 \\
M2 & 88.00 & 70.25 & 6.09 & 15.29 & 25.75 \\
M3 & 84.00 & 67.00 & 7.71 & 11.81 & 24.22 \\
M4 & 89.00 & 74.00 & 6.05 & 15.15 & 27.20 \\
M5 & 85.00 & 68.00 & 8.61 & 16.18 & 23.79 \\
M6 & 89.00 & 75.00 & 5.00 & 13.47 & 20.89 \\
M7 & 80.00 & 62.00 & 4.46 & 14.02 & 23.81 \\
M8 & 87.00 & 70.00 & 5.95 & 18.75 & 22.85 \\
M9 & 83.00 & 65.00 & 4.90 & 14.41 & 18.44 \\
L.S.D. 0.05 & 5.00 & 3.16 & 0.56 & 0.93 & 1.52 \\
\hline
\end{tabular}

It was reported that, during pollen development and maturation, high temperatures tend to reduce the pollen carbohydrates as a result of high respiration rate and also decreased the viability of the pollen grains (Pressman et al., 2002). Also, all factors that influence the photosynthetic rate would result in less carbohydrate accumulation in the mature pollen (AlTahir et al., 1982).

As for the amino acids content in the different pollen grains, the data presented in Tables ( $3 \& 4)$ showed that the nine date palm male sources contained 8 essential amino acids and 9 nonessential

ones (Hassan, 2011). Concerning the essential amino acids, the results in Table 3 indicated that M3 had a higher isolucine content followed by M1 and M5 as compared to all other male sources, while M7 had the lowest isolucine value. It was also noticed that M6 had significantly the higher leucine content followed by M9 as compared to all other male source, while M5 had the lowest leucine value. In the Meantime, M1 had significantly the higher lysine content followed by M6, M5 and M2 in comparison to all other male sources, while both M8 and M9 contained the lowest values.

Table 3: Essential amino acid contents of different date palm pollen sources ( $\mathrm{g} / 100 \mathrm{~g}$ protein).

\begin{tabular}{lcccccccc}
\hline No. Male & \multicolumn{8}{c}{ Essential amino acids* } \\
\cline { 2 - 9 } & Ile & Leu & Lys & Phe & Thr & Val & His & Met \\
\hline M1 & 6.14 & 6.83 & 6.41 & 4.23 & 4.24 & 4.95 & 2.98 & 1.25 \\
M2 & 5.42 & 6.40 & 6.12 & 3.96 & 4.32 & 4.84 & 2.58 & 1.22 \\
M3 & 6.33 & 4.65 & 5.76 & 4.84 & 3.68 & 5.02 & 2.61 & 1.14 \\
M4 & 5.65 & 6.30 & 5.58 & 4.52 & 4.12 & 5.00 & 2.56 & 0.99 \\
M5 & 6.13 & 3.75 & 6.17 & 3.69 & 3.65 & 5.62 & 2.70 & 1.21 \\
M6 & 4.33 & 8.19 & 6.20 & 3.08 & 3.25 & 4.64 & 3.44 & 1.53 \\
M7 & 4.06 & 6.29 & 5.55 & 3.39 & 3.00 & 3.35 & 4.24 & 1.35 \\
M8 & 4.86 & 6.35 & 5.16 & 3.72 & 3.07 & 3.19 & 2.27 & 1.36 \\
M9 & 4.28 & 7.64 & 5.31 & 3.23 & 3.73 & 3.85 & 2.75 & 1.45 \\
L.S.D.05 & 0.16 & 1.21 & 0.18 & 0.20 & 1.02 & 0.24 & 0.16 & 0.10 \\
\hline II:
\end{tabular}

*: Ile: (Isolucine), Leu: (Leucine), Lys: (Lysine), Phe: (Phenylalanine), Thr: (Threonine), Val: (Valine), His: (Histidine), Met: (Methionine).

Table 4: Nonessential amino acid contents of pollens of the different date palm sources ( $\mathrm{g} / 100 \mathrm{~g}$ protein).

\begin{tabular}{|c|c|c|c|c|c|c|c|c|c|}
\hline \multirow{2}{*}{ No. Male } & \multicolumn{9}{|c|}{ Nonessential amino acids* } \\
\hline & Ala & Arg & Asp & Glu & Gly & Ser & Cys & Tyr & Pro \\
\hline M1 & 6.10 & 5.17 & 11.25 & 10.83 & 4.23 & 4.80 & 0.32 & 3.52 & 3.95 \\
\hline M2 & 6.26 & 4.60 & 11.35 & 11.18 & 3.74 & 3.77 & 0.23 & 3.52 & 4.14 \\
\hline M3 & 6.13 & 5.05 & 9.41 & 10.53 & 4.79 & 4.46 & 0.38 & 3.37 & 3.90 \\
\hline M4 & 5.80 & 4.84 & 12.00 & 11.31 & 3.65 & 4.19 & 0.41 & 3.22 & 3.09 \\
\hline M5 & 5.44 & 4.41 & 13.08 & 12.51 & 4.17 & 4.73 & 0.32 & 2.96 & 3.75 \\
\hline M6 & 4.59 & 5.80 & 8.50 & 8.61 & 3.10 & 4.06 & 0.29 & 4.20 & 1.37 \\
\hline M7 & 4.50 & 4.15 & 8.99 & 9.32 & 4.1 & 3.28 & 0.30 & 3.22 & 1.69 \\
\hline M8 & 4.39 & 4.85 & 9.23 & 7.75 & 4.42 & 3.42 & 0.39 & 3.32 & 1.61 \\
\hline M9 & 4.63 & 4.23 & 9.42 & 9.91 & 4.20 & 2.55 & 0.29 & 3.16 & 1.44 \\
\hline L.S.D. ${ }_{0.05}$ & 0.20 & 0.15 & 2.81 & 0.30 & 0.17 & 0.28 & 0.02 & 0.23 & 0.18 \\
\hline
\end{tabular}

*: Ala: (Alanine), Arg: (Arginine), Asp: (Aspartic acid), Glu: (Glutamic acid), Gly: (Glycine), Ser: (Serine), Cys: (Cystine), Tyr: (Tyrosine), Pro: (Proline) 
Meanwhile, M3 had significantly higher phenylalanine content followed by M4 as compared to all other male sources, while M6 and M9 had the lowest value of phenylalanine. In the meantime, M1, M2 and M4 had significantly higher values of threonine content than the other male sources, while M6, M7 and M8 had the lowest threonine content. In addition, M5 had a significant higher valine content followed by M3, M4 and M1, while both M7 and M8 had the lowest significant valine content. Furthermore, M7 had a higher histidine content followed by M6 than the other male sources, while M8 contained the lowest histidine value. Furthermore, M6 and M9 had a significant higher methonine content as compared with that of the other male sources, while M4 contained the lowest methionine value. The values of essential amino acids contents of the other sources of pollen grains were inbetween these two extremes

In accordance to the nonessential amino acids, the results in Table (4) indicated that M1, M2 and M3 had the highest significant alanine content in comparison with the other male sources, while M8 had the lowest alanine content. It was also noticed that M6 had the higher significant arginine content followed by M1 and M3 than the other male source, while M7 had the lowest value. In the Meantime, M1, M2, M4 and M5 had significantly the higher aspartic acid content, while the remained males had the lowest aspartic acid content.

Furthermore, M5 had significantly the higher glutamic acid content followed by M4 and M2 than the other male sources, while M8 had the lowest significant value. In the meantime, M3 had the higher significant glycine content followed by M8 than the other male sources, while M6 had the lowest glycine content. In addition, M1, M3 and M5 had significantly the higher serine content, while M9 contained the lowest value. Furthermore, M3, M4 and M8 had significantly the higher cystine content than the other male sources, while M2 had the lowest value. Furthermore, M6 had significantly the higher tyrosine content followed by M1, M2, M3 and M8, while M5 and M9 had the lowest significant tyrosine content. In the meantime, M2 had significantly the higher proline content followed by M1, M3 and M5, while M6, M8 and M9 had the lowest significant values of proline content. The values of nonessential amino acids contents of the other sources of pollen grains were inbetween these two extremes.

Different sources for date palm pollens showed a different combination of amino acids, similar results were recorded by Bishr and Desoukey (2012). Many studies have shown that 2-5 amino acids constitutes almost $50 \%$ of the protein weight in the pollen and the remaining amino acids (15 to 18) constitutes to the other 50\% (Szczêsna, 2006). Amino acids content of pollen grains varied according to the climatic and nutritional conditions of the plants (Stanley, 1971).

\section{Correlation analysis}

Correlation coefficients among the staining and germinating percentage of pollen grains on one side and their chemical composition on the other one are presented in Table (5). The data showed that there was a positive significant correlation between stained and germinated pollen grains $(r=0.939)$. These results indicated that high staining percentage of pollen grains positively correlated to the germination percentage of the pollen grains.

Furthermore, both stained and germinated pollen grains were positively correlated with all the chemical constitutes in the pollen except for histidine, methionine and glycine which showed a negative correlation. The highest positive significant correlation was found between both stained and germinated pollen grains on one side and their content of arginine on the other one. This indicates that arginine can be used as an indicator of the viability of the pollen grain as compared with that of all other male sources.

Table 5: Correlation coefficient among stained and germinated pollen grains on one side and their chemical composition on the other one.

\begin{tabular}{lcc}
\hline Variables & Stained & Germinated \\
\hline Stained & 1 & \\
Germinated & 0.939 & 1 \\
Total sugars & 0.180 & 0.132 \\
carbohydrates & 0.183 & 0.019 \\
Protein & 0.567 & 0.646 \\
Isolusine & 0.418 & 0.402 \\
Leucine & 0.261 & 0.296 \\
Lysine & 0.532 & 0.606 \\
Phenylalanine & 0.274 & 0.248 \\
Threonine & 0.551 & 0.495 \\
Valine & 0.451 & 0.423 \\
Histidine & -0.416 & -0.198 \\
Methionine & -0.195 & -0.123 \\
Alanine & 0.436 & 0.397 \\
Arginine & 0.693 & 0.700 \\
Aspartic acid & 0.352 & 0.280 \\
Glutamic acid & 0.124 & 0.110 \\
Glycine & -0.403 & -0.320 \\
Serine & 0.541 & 0.593 \\
Cystine & 0.088 & 0.090 \\
Tyrosine & 0.488 & 0.489 \\
Proline & 0.354 & 0.319 \\
\hline Pricipal component & analysis &
\end{tabular}

\section{Principal component analysis}

When analyzing a large number of multivariate variables, it is desirable to reduce their dimensionality using the PCA technique. The original variables are replaced with a smaller number of derived variables and most of the variability is retained Jolliffe (2002). A principal component analysis (PCA) was performed to clarify the relationship between the different evaluated variables. The Eigen value of each principle component is presented in Table (6). The PCA1, 
PCA2, PCA3 and PCA4 explained $44.914 \%, 20.805$ $\%, 10.440 \%$ and $7.147 \%$ of the total variance, and all of them contributed to $83.68 \%$ (Table, 6 ). In the plot (Figure 1) the weight of the different variables are presented with vectors and are shown to vary from the origin. The longer are the vectors, the greater are the loadings. Carbohydrates, histidine and cystine had lower weights as compared to the other amino acids. Thus, they contributed less to explain the data variance.
The biplot enabled the evaluation among the quantified variables, with lines presenting the same direction being more closely correlated. Serine, valine, protein content and are highly correlated also glutamic, aspartic acid, phenylaalaine and total sugars are highly correlated. There was a high correlation between the stained, germinated pollen grains and the content of lysine and arginine. Males number 7, 8 and 9 were similar in their chemical content having the lowest level of the studied chemical content.

Table 6: Principle component analysis

\begin{tabular}{lcccc}
\hline & PCA1 & PCA2 & PCA3 & PCA4 \\
\hline Eigenvalue & 9.881 & 4.577 & 2.088 & 1.429 \\
Variability $(\%)$ & 44.914 & 20.805 & 10.440 & 7.147 \\
Cumulative \% & 44.914 & 65.719 & 76.528 & 83.675 \\
Stained & 0.157 & 0.328 & 0.064 & -0.149 \\
Germinated & 0.148 & 0.346 & -0.043 & 0.533 \\
Total sugars & 0.256 & -0.137 & 0.090 & 0.112 \\
Carbohydrates & -0.033 & -0.119 & 0.137 & -0.033 \\
Protein & 0.234 & 0.097 & 0.030 & 0.335 \\
Isolusine & 0.306 & -0.049 & -0.134 & -0.123 \\
Leucine & -0.189 & 0.301 & 0.296 & -0.012 \\
Lysine & 0.180 & 0.290 & -0.178 & 0.331 \\
Phenylalanine & 0.250 & -0.092 & -0.078 & -0.049 \\
Threonine & 0.239 & 0.090 & -0.169 & -0.485 \\
Valine & 0.270 & 0.105 & -0.065 & -0.086 \\
Histidine & -0.150 & 0.099 & -0.015 & 0.037 \\
Methionine & -0.256 & 0.156 & 0.465 & 0.099 \\
Alanine & 0.290 & 0.041 & -0.284 & 0.231 \\
Arginine & 0.046 & 0.375 & -0.340 & -0.056 \\
Aspartic acid & 0.253 & -0.080 & 0.151 & -0.317 \\
Glutamic acid & 0.257 & -0.092 & 0.189 & -0.143 \\
Glycine & 0.061 & -0.333 & 0.503 & 0.054 \\
Serine & 0.264 & 0.129 & 0.245 & 0.072 \\
Cystine & 0.068 & -0.154 & -0.071 & -0.036 \\
Tyrosine & -0.067 & 0.425 & 0.064 & -0.149 \\
Proline & 0.301 & -0.024 & -0.043 & 0.533 \\
\hline
\end{tabular}

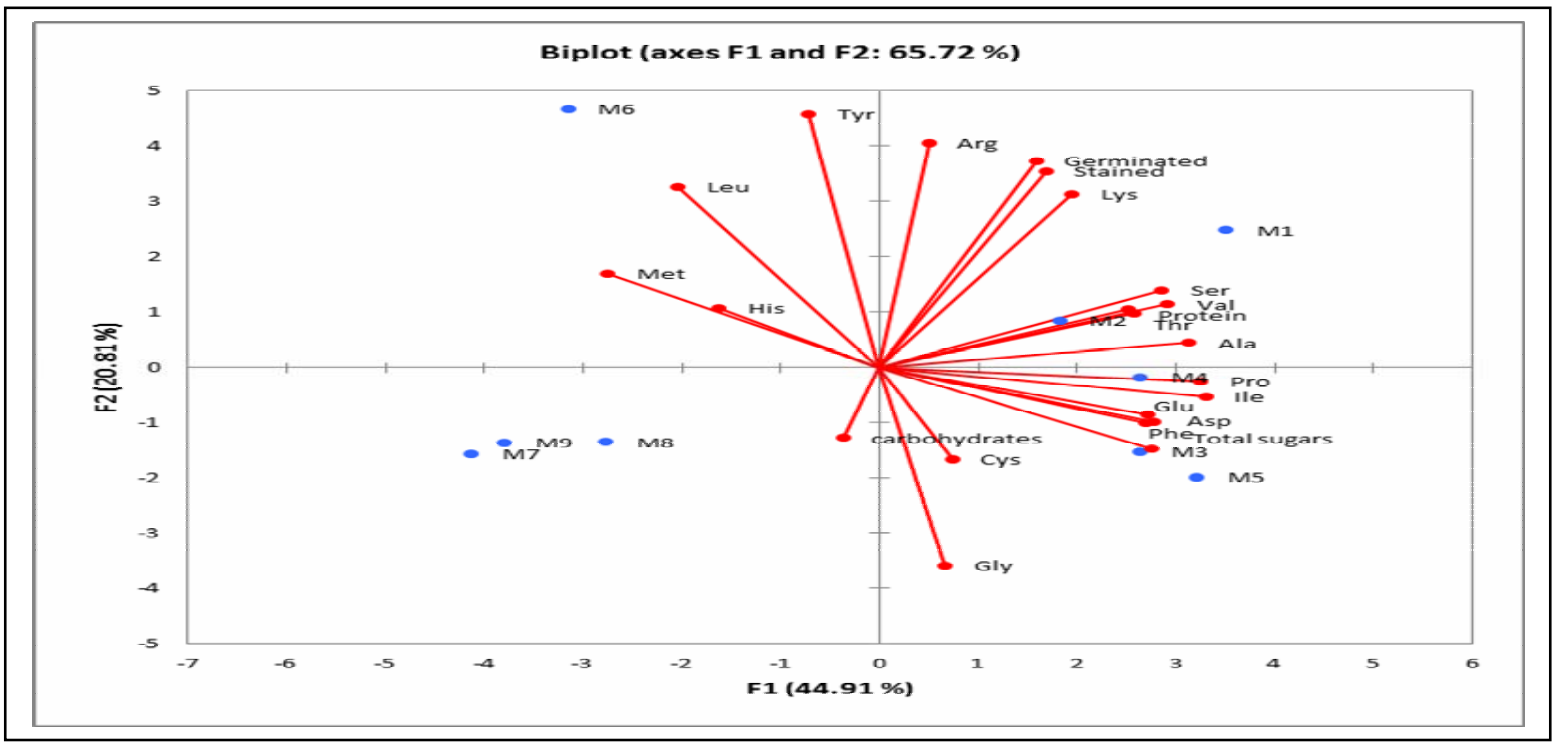

Figure 1: Biplot of the first two principle component axes for the chemical content of the pollen grains 
The figure also illustrated that carbohydrate content located on the left side of the PCA1. Major chemicals defining the first principle component were total sugars, isolusine, valine, alanine, glutamic acid, serine and proline. The second principle component was mainly characterized by arginine and tyrosine. Males 3 and 5 were characterized by large amount of total sugar.

\section{CONCLUSION}

From the above mentioned results, it is generally noticed that pollen viability and chemical composition differed extremely in accordance to the different male source studied. This cleared that it (pollen viability) affected by both environmental factors in addition to genetic constituents of pollen grains of each source. It can be concluded that both arginine and lysine of pollen grains are more correlated to pollen viability. Thus, this study needs to how to increase the concentration of these two amino acids in pollen grains using some genetic markers to suitable male palm trees to increase the productivity of the female ones.

\section{REFERENCES}

Al-Tahir, O. A.; M. A. Abdul Salam; A. S. AlGhamdi and S. A. Al Khateeb (1982). Study of the chemical composition of pollen grains in some date palm (Phoenix dactylifera L.) males. Third Symposium on date palm in Suid Arabia, 261- 264.

A.O.A.C. (1995). Association of Official Agricultural Chemists, Official Methods of Analysis $16^{\text {th }}$ Edn. Published by A.O.A.C. Washington, USA.

Bacha, M. A.; T. A. Naser and M. A. Shaheen (1988). Pollination studies in relation to productivity of date palm in the central region, Saudi Arabia. Management of scientific research, King Abdul-Aziz City for science and Technology, Riyadh, Saudi Arabia. Edited by KACST, 1988. 320 p

Bacha, M. A. A.; M. A. Aly; R. S. Al-Obeed and A. O. Abdul-Rahman (2000). Compatibility relationship in some date palm cultivars (Phoenix dactylifera L.). J. King Saud Univ. Agric. Sci., 12(2): 81-95.

Bishr, M. and S. Y. Desoukey (2012). Comparative study of the nutritional value of four types of Egyptian palm pollens. J. Pharm. Nut. Sci., 2, 50-56.

Block, R. J.; E. L. Durrum and G. Zweig (1958). A Manual of Paper Chromatography and Paper Electrophoresis, 2 nd Ed. Academic Press, Inc. New York.

El-Hammady, M. M.; A. S. Khalifa and A. M. AlHammady (1977). The effect of date pollen on some physical and chemical characters of Hayani variety. Res. Bull. 737, Fac. Agric, Ain Shams Univ. Cairo.
El-Makhtoun, F. M. and A. M. M. Abd-ElKader (1990). Effect of different pollen types on fruit setting, yield and some physical properties of some date palm varieties. Agric. Res. Rev., 68(5): 957-971.

El-Makhtoun, M. (1981). Effect of different pollen types on fruiting and fruit quality in some date varieties. M.Sc. Hort. Dept., Fac. of Agric., El-Azhar Univ., Egypt.

Fahmy, T. (2015). Microsoft R Excel 2013/XLSTATc-Pro (Version 2015, 6.01.23953, Addinsoft, Inc., Brooklyn, NY, USA).

Hamdy, Z. M. (1982). Effect of source of pollen on the physical quality of Amhat date variety. Agric. Res. Rev., 60, 5-22.

Hassan, H. M. M. (2011). Chemical composition and nutritional value of palm pollen grains. Global J. Biotech. \& Biochem., 6 (1): 1-7.

Ibrahim, A. M. F. (1989). Germination of date palm (Phoenix dactylifera L.) J. Agric. Sci. Mansoura Univ., 14, 1729-1733.

Ibrahim, I. A.; H. A. Emara; A. A. Nower and M. S. Atfi (2014). In vitro study on germination of date palm pollen grains and its impact on fruit quality. Life Sci. J., 11, 1291-1300.

Iqbal, M.; A. Ghaffoor; A. Jalal ud din and M. Munir (2008). Effect of different date male pollinizer on fruit characteristics and yield index of date palm (Phoenix dactylifera L.) cv. Zahidi and Dhakki. Pakistan J. Agric. Res., 21 (4):79-85.

Jolliffe, Ian (2002). Principal component analysis. John Wiley \& Sons, Ltd.

Khalifa, A.; S. Azzouz; Z. M. Hamdy; H. El-Masry and M. Yousef (1980). Effect of source of pollen on the physical and chemical quality of "Amhat" date variety. Agric. Res. Rev., 58(3): 15-23.

Malik, C. P. and M. B. S. Singh (1980). Plant Enzymology and Histoenzymology. A Text Manual, Kalyani Publishers, New Delhi.

Merwad, M. A.; E. A. M. Mostafa; M. M. S. Saleh and A. A. Mansour (2015). Yield and fruit quality of Hayany date palm as affected by different pollen grain sources. Int. J. Chem. Tech. Res., 8 (6): 544-549.

Moore, S.; H.D. Spackman and W.H. Stein (1958). Chromatography of amino acids on sulphonated polystyrene serins: An improved method. Anal. Chem., 30, 1185-1190.

Mustafa, E. A. M.; S. A. A. Heiba; M. M. S. Saleh; N. E. Ashour; Dorria A. Mohamed and M. M. M. Abd El-Migeed (2014). Effect of different pollinizer sources on yield, fruit characteristics and phylogenetic relationships with Amhat cv. date palm (Phoenix dactylifera L.) in Egypt using RAPD markers. Int. J. Agric. Res., 9 (7): 331-343. 
Nesiem, M. R. A.; E. Darwish; G. Gadalla and F. Shaimaa (2016). Comparison study among pollen grains of three date palm males cultivars (phoenix dactylifera L.) J. Biol. Chem. Environ. Sci., Vol.11 (3): 263-275.

Pressman, E.; M. M. Peet and D. Pharr (2002). The effect of heat stress on tomato pollen characteristics is associated with changes in carbohydrate concentration in the developing anthers. Annals of Botany 90.5: 631-636.

Rabie, I. S. (2007). Evaluation of date palm males used in pollination in Rasheed Region, Egypt. Alex. J. Agric. Res., 52 (1), 91-102.
SAS Institute Inc. (2008). The SAS System for Windows, Version 9.13, SAS Institute Inc., Cary, NC, USA. Singh, Z. and L. Singh.

Snedecor, G. W. and W. G. Cochran (1980). Statistical methods 7 th Ed. Iawa state Univ. press Ames, lowa, U.S.A PP 507.

Stanley, R. G. (1971). Pollen chemistry and tube growth. Pollen: development and physiology, 1971, 131-155.

Szczêsna, T. (2006). Protein content and amino acid composition of bee-collected pollen from selected botanical origins. J. Apicultural Sci., 50.2: $81-90$.

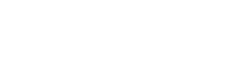

\section{حيوبة لفاح نخل البلح من مصادرمختلة وعلافتها بالتركيب الكيماوى}

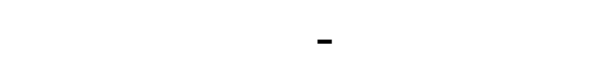

'قتم الفلكهة - كلية الزراعة - جلمعة الإبكندرية

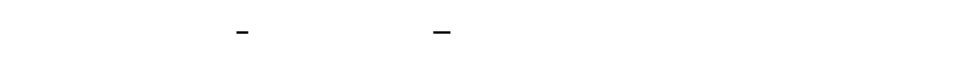

لجريت هذه الدرلسة بهرف قلقير حيوية حبوب لقاح من تشعة مصادر من نكور نخيل البلح فى ثلاث منطلق

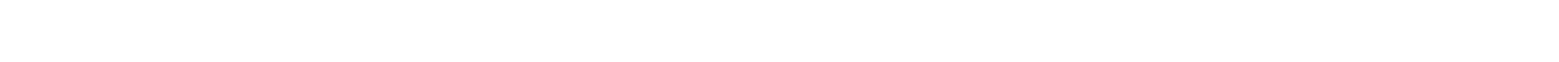

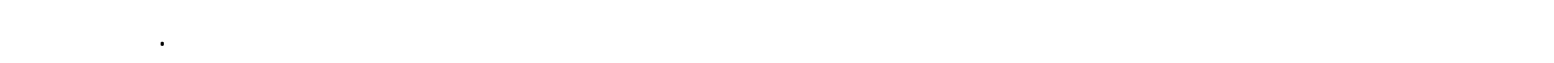

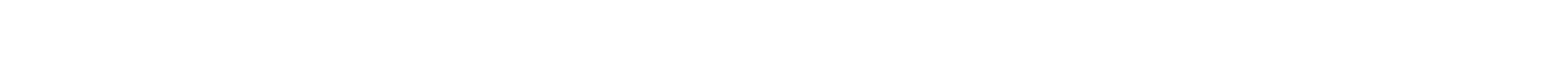

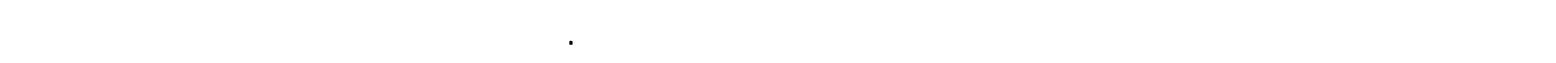

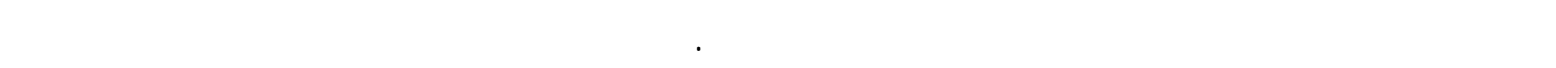

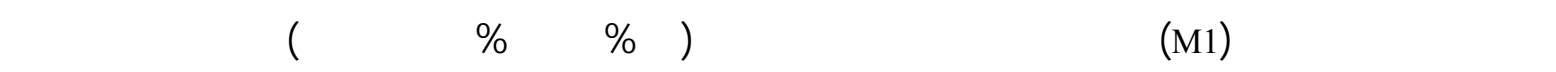

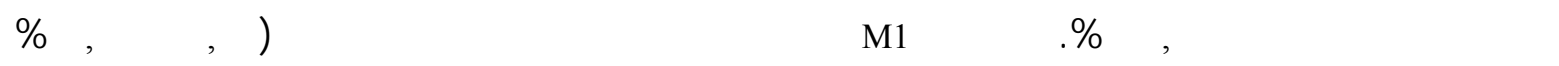
على التواله) بالمقارنة بمصادر حبوب الفاح الأخرى. ووجدت علاقة تلازم موجبة بين حبوب القاح المصبوغة

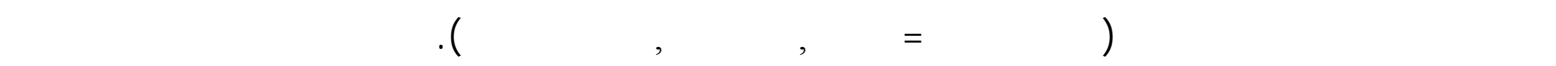

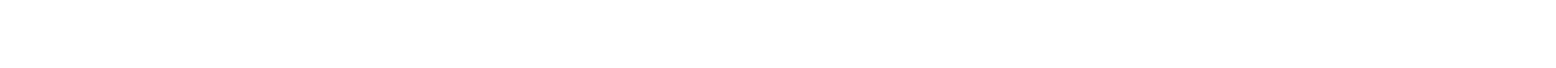

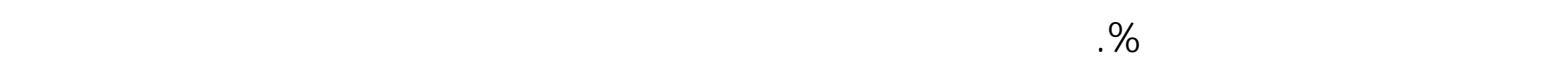
حبوب القاح المصبوغة والمنبتة ومحتواها من الليسين والأرجينين. 